\title{
Microarchitecture of the Palatine Tonsil in Sheep (Ovis aries)
}

\author{
Microarquitectura de la Tonsila Palatina en Oveja (Ovis aries)
}

"N. K. B. Raju; ${ }^{* *}$ Geetha Ramesh; ${ }^{* * *}$ Sabiha Hayath Basha; ${ }^{* * *}$ S. Ushakumary $\&{ }^{* * * *}$ P. V. S. Kishore

\begin{abstract}
RAJU, N. K. B.; RAMESH, G.; BASHA, S. H.; USHAKUMARY, S. \& KISHORE, P. V. S. Microarchitecture of the palatine tonsil in sheep (Ovis aries). Int. J. Morphol., 30(4):1481-1486, 2012.

SUMMARY: The tissue pieces of palatine tonsil were collected from different postnatal age groups of sheep from the Corporation Slaughter House, Perambur, Chennai. The palatine tonsil consisted of a surface epithelium, capsule, tonsillar lobes, crypts, crypt epithelium and tonsillar follicles. The surface epithelium over the palatine tonsil was made up of non-keratinized stratified squamous epithelium in all the postnatal age groups studied. The palatine tonsil was clearly demarcated from the surrounding structures by a distinct connective tissue capsule and one septa dividing the tonsil into two lobes. The surface epithelium was invaginated into the substance of the tonsil to form primary and secondary crypts in each lobe. The crypt epithelium covered the regions of lymphoid follicles became lymphoepithelium. The macrophages were also observed in the epithelium. In the areas of lymphoepithelium the basement membrane was interrupted since lymphocytic infiltration was heavy into the epithelium. Numerous secondary tonsillar follicles with germinal centers separated by interfollicular areas were observed in the palatine tonsil. The tonsillar follicles consisted of a mantle zone, which was heavily populated with small darkly stained lymphocytes. These mantle zones were always oriented towards the crypts. The tonsillar follicles of young sheep showed many medium and small sized lymphocytes, lymphoblasts and also reticulocytes. The reticular cells usually appeared larger than lymphocytes and had a more abundant and organized cytoplasm with vacuoles.
\end{abstract}

KEY WORDS: Sheep; Palatine tonsil; Crypts; Follicles.

\section{INTRODUCTION}

Palatine tonsils occupy a significant position at the beginning of the gastrointestinal tract allowing intimate contact with bacteria and other antigens that are ingested. Banks (1993) and Dellmann \& Eurell (1998) stated that the aggregated lymphatic nodules in the pharynx or caudal oral cavity are referred to as tonsils in domestic animals. Cooper et al. (1967) stated that the palatine tonsil is a representative of gut-associated lymphoid tissue. All the tonsils (palatine tonsil, lingual tonsil, tonsil of the soft palate, pharyngeal tonsil, tubal tonsil and paraepiglottic tonsil) together form a ring of lymphoid tissue in the pharyngeal wall called the "Waldeyer ring" (Nickel et al., 1979; Perry \& Whyte, 1998). The palatine tonsils composed primarily of follicles are known as follicular tonsils (Nickel et al.).

The palatine tonsil play a key role in initiating immune responses against the antigenic material entering the mouth and their lymphatic pathways are important in disseminating immunological information to the lymph nodes and other mucosal surfaces (Brandtzaeg, 1984; Belz and Heath, 1995a) in dogs.

Perry (1994) termed the mixing of lymphoid and epithelial cells in the crypt epithelium of palatine tonsil as "lymphoepithelial symbiosis" in mammals. The reticulated crypt epithelium, the lymphoepithelium (Perry \& Whyte) plays a key role in immune responses in the palatine tonsil (Karchev \& Kabakchiev, 1982; Belz \& Heath, 1995b).

A thorough knowledge of the histological structure of the palatine tonsil is very essential to gain a comprehensive knowledge on the gut immunology and to form a basis for the interpretation of various pathological conditions of the gut. Hence, the present work has been undertaken to explore the postnatal development of the palatine tonsil in sheep.

\footnotetext{
* Assistant Professor, Department of Veterinary Anatomy, NTR. College of Veterinary Science, Andhra Pradesh, India.

** Professor and Head, Department of Veterinary Anatomy, Madras Veterinary College, Chennai, India.

${ }^{* * *}$ Associate Professor, Department of Veterinary Anatomy, Madras Veterinary College, Chennai, India.

****A Associate Professor, Department of Veterinary Anatomy, NTR. College of Veterinary Science, Andhra Pradesh, India.
} 


\section{MATERIAL AND METHOD}

Tissue pieces of palatine tonsil in the area of oropharynx were collected from sheep. These tissues, six each from different age groups viz. neonatal (0-2 months), young (3-9 months) and adult (10 months- 2 years) were procured from the Corporation slaughter house, Perambur, Chennai. The determination of age was ascertained as per the procedure described by Noden \& de Lahunta (1985).

For light microscopy the tissue pieces were fixed in different fixatives viz., 10 per cent neutral buffered formalin, Bouin's fluid and Zenker's fluid. They were processed for

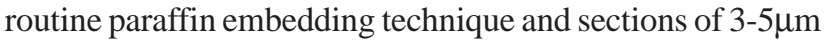
thicknesses were cut. The paraffin sections were subjected to routine and special histological staining methods viz.Masson's trichrome (Luna, 1968), Gomori's method (Luna), Toluidine blue (Singh \& Sulochana, 1996) and Ayoub-Shklar method (Luna).

For transmission electron microscopy, the semi thin sections of 200-300nm thickness and ultra thin sections of $50-70 \mathrm{~nm}$ were cut with a Leica Ultracut UCT-GA-D/E-1/ 00 ultra microtome. The semi thin sections were stained with toluidine blue. The ultra thin sections were mounted on grids and stained with saturated aqueous uranyl acetate and counter stained with 4\% lead citrate (Bozzola \& Russell, 1998).

\section{RESULTS AND DISCUSSION}

The palatine tonsil consisted of a surface epithelium, capsule, tonsillar lobes, crypts, crypt epithelium, tonsillar follicles, blood vessels and lymph vessels in all the postnatal age groups of sheep. Nickel et al., described that the palatine tonsils were composed primarily of follicles in domestic animals. Banks stated that the tonsils consisted of solitary and aggregated nodules in domestic animals. Nave et al., (2001) described that the specialized compartments of the palatine tonsils were the crypt epithelium, lymphoid follicle and extracellular region in humans.

Tonsillar surface epithelium. The surface epithelium over the palatine tonsil was made up of non-keratinized stratified squamous epithelium in all the age groups studied (Fig. 1). This is in accordance with the findings of Anderson (1974) in piglet, Perry in humans, Belz \& Heath (1995b) in dog and Velinova et al. (2001), in bovines. However, Dellmann \& Eurell stated that in domestic animals, the tonsils were covered by stratified squamous epithelium. Cocquyt $e t$ al. (2005), also reported the similar observation in ovine.

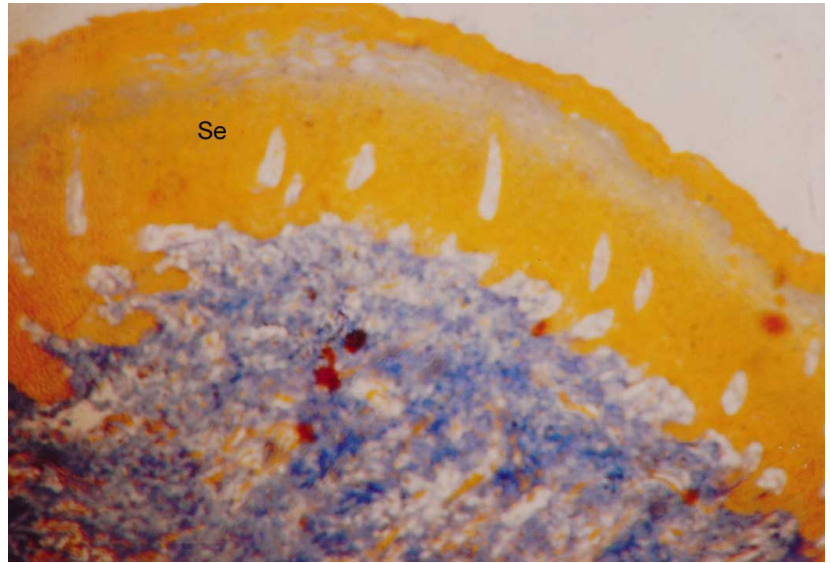

Fig. 1. Photomicrograph of palatine tonsil of one year-old sheep showing non-keratinized stratified squamous surface epithelium. Se. Surface epithelium. Ayoub-Shklar x 100.

Contrary to this, Castelyn et al. (2007), observed that the palatine tonsils were covered by keratinized stratified squamous epithelium in ovine.

The number of cell layers in the surface epithelium varied from three to ten in neonatal to adult age groups. But, Perry noted that the surface epithelium was approximately 15-20 cells thick in humans. The height of the epithelium was $155.00+6.42 \mu \mathrm{m}$ in neonatal and it increased to $360.00 \pm 9.31 \mu \mathrm{m}$ in young and 795.50+5.24 $\mu \mathrm{m}$ in adult age group.

In all the age groups, the tonsillar surface epithelium invaginated into underlying tissue to form primary tonsillar crypts, which inturn formed secondary crypts. Velinova et al., made a similar observation in bovines and Castelyn et al., in ovine.

The infiltration of surface epithelium by lymphocytes was not observed in all the postnatal age groups of sheep. Contrary to this, Perry in humans, Belz \& Heath (1995b) in dog and Dellmann \& Eurell (1998) in domestic animals found the infiltration of surface epithelium with variable degree of lymphocytes, neutrophils and macrophages.

Capsule of tonsil. The palatine tonsil was clearly demarcated from the surrounding structures by a distinct connective tissue capsule in all the postnatal age groups studied which is in total agreement with the observations of Dellmann \& Eurell in domestic animals, Cocquyt et al., in ovine and Castelyn et al., in ovine. The capsule was mainly composed of collagen and reticular fibres. Few smooth muscle fibres were also noticed within the capsule, which is corroborated with the findings of Velinova et al., in bovine. However, Cocquyt et al., and Castelyn et al., stated that, the capsule consisted of dense collagenous tissue in ovine. 
The median septa from the capsule entered into the parenchyma and divided the tonsil into a bilobed structure. Within the fibers of median septa few blood vessels were also observed. Palatine glands were also found to be trapped by the fibers of septa particularly in neonatal and young age groups. The thickness of the capsule increased from neonatal to young animals and it remained the same without any change in adults. The average thickness of the capsule was $127.50+11.45 \mu \mathrm{m}$ in neonatal $165.00 \pm 12.84 \mu \mathrm{m}$ in young and $215.00+18.43 \mu \mathrm{m}$ in adult age groups.

Tonsillar lobe. The palatine tonsil was bilobed. It was clearly divided into two lobes by median connective tissue septa from the capsule. Each lobe consisted of primary and secondary crypts along with numerous lymphoid follicles. Cocquyt et al., stated that the capsule invaginated the palatine tonsil once or twice and divided it into two or three lobes in ovine. However, Belz \& Heath (1995b) found that the pharyngeal mucosa was folded and divided the lymphoid tissue into several lobes in canine.

Crypts. The tonsillar surface epithelium penetrated and invaginated into the substance of the tonsil to form primary crypts, which in turn formed secondary crypts, hence, an intimate relationship between the lymphocytes of the parenchyma and the crypt epithelium was observed in all age groups. Anderson reported a similar observation in piglets, whereas Williams \& Rowland (1972) observed an extensively ramified tonsillar crypt system in the pig.

The primary crypt had a large lumen and was frequently branched to form secondary crypts. Numerous secondary lymphoid follicles were located in the walls of the crypts. These findings are in total agreement with the observations of Cocquyt et al., and Castelyn et al., in ovine. Each primary crypt had a large lumen which was sometimes occluded by mucus or cellular debris. This is in corroboration with the description of Perry in humans and Castelyn et al., in ovine.

Crypt epithelium. The epithelium of the tonsillar crypts was non-keratinized stratified squamous epithelium (nonreticular epithelium). This is in agreement with the observations of Cocquyt et al., and Castelyn et al., in ovine and Palmer et al. (2009), in bovine. It consisted of a basal layer of columnar cells, three to five rows of polyhedral cells in the middle layer and an outer layer of horizontally oriented squamous cells.

The crypt epithelium where it overlaid or covered the regions of lymphoid follicles became lymphoepithelium (reticular epithelium). In these areas of lymphoepithelium, the different cell layers of stratified squamous epithelium were found to be minimal and got replaced by abundant lymphocytes and the layers were indistinct. An infiltration of macrophages, plasma cells, dendritic cells and neutrophils into the crypt epithelium was observed. A similar observation of lymphoepithelium of the crypt was reported by Curran \& Jones (1977) in humans, Higashikawa et al. (1990), in rabbit, Perry \& Mustafa (1992), Morente et al. (1992), and Perry in humans, Velinova et al., in bovine, Cocquyt et al., and Castelyn et al., in ovine and Palmer et al., in bovine. Further, the reticular fibers were also noticed in the reticular epithelium (Fig. 2) but their occurrence in the epithelium was minimal as compared to lymphocytes. The venules were also found within the lower portion of the reticular epithelium.

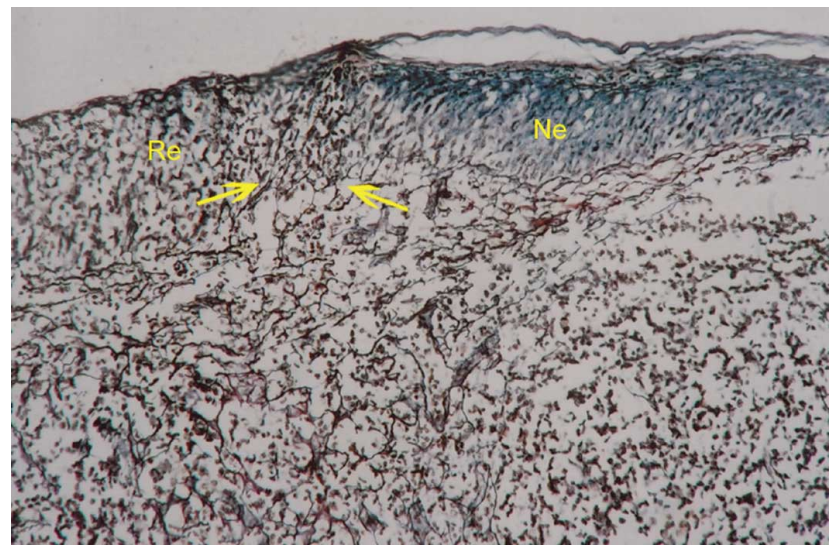

Fig. 2. Photomicrograph of palatine tonsil of four month-old sheep showing a reticular epithelium (lymphoepithelium) with reticular fibres (arrows). Re. Reticular epithelium; Ne. Non reticular epithelium. Gomori's reticulum x 200.

Ultrastructurally, macrophages were observed in the crypt epithelium. Their cytoplasm had vacuoles, phagocytosed materials, granules, mitochondria and endoplasmic reticulum. The nucleus appeared round to oval in shape with little chromatin (Fig. 3). This is in accordance with the reports of Higashikawa et al. (1990), in rabbits. Rappolee \& Werb (1992) and Cross \& Mercer (1993) in mammals. They described that the lysosomes were particularly developed in the macrophages. They contained accumulation of heterogenous bodies in secondary lysosomes, which represented phagocytosed material in the process of digestion.

In the areas of reticular epithelium, the basement membrane was interrupted since lymphocytic infiltration was heavy which is in accordance with the findings of Cocquyt et al., in ovine. The surface of the reticular epithelium was covered by one or two layers of horizontally oriented squamous cells (Fig. 4). In some areas, the lymphocytes 


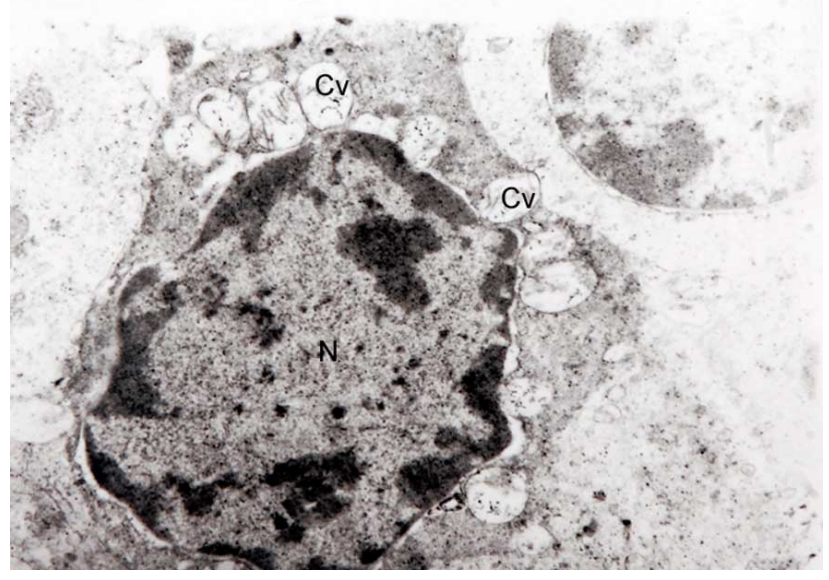

Fig. 3. Transmission electronmicrograph of palatine tonsil of six month-old sheep showing a macrophage in the crypt epithelium. N. Nucleus; Cv-Cytoplasmic vacuoles. Uranyl acetate and Lead citrate x 12530 .

entered into the lumen of the crypt through the reticular epithelium, which is in total agreement with the observations of Perry in humans. Howie (1980) in humans, Belz \& Heath (1995b) and Bernstein et al. (1999), in dog reported that the reticular epithelium (lymphoepithelium) of crypts contained M-cells.

Tonsillar follicles. Numerous secondary tonsillar follicles with germinal centers separated by interfollicular areas were observed in the palatine tonsil which is in accordance with the observations of Anderson in piglet, Belz \& Heath (1995b) in canine, Dellmann \& Eurell in domestic animals, Velinova et al. in bovine, Thuring et al. (2002), Cocquyt et al., in sheep and Liebler-Tenorio \& Pabst (2006) in three weeks-

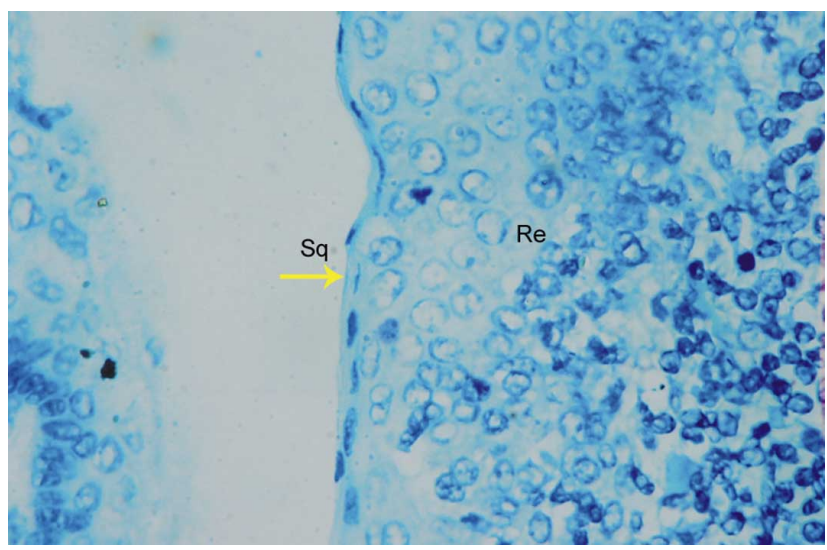

Fig. 4. Photomicrograph of palatine tonsil of two month-old sheep showing an outer squamous cell layer in the reticular epithelium of the crypt. Re. Reticular epithelium; Sq. Squamous cell layer. Toluidine blue x 630 . old calves. The follicles were rounded or oval in shape and were noticed in all the postnatal age groups. Each follicle consisted of outer darker and inner lighter zones, which is in agreement with the findings of Velinova et al., in bovine.

The tonsillar follicles consisted of a mantle zone, which was heavily populated with small darkly stained lymphocytes. These mantle zones were always oriented towards the crypts. Numerous macrophages and reticular cells were also localized in the mantle zone which is in accordance with the observations of Dellmann \& Eurell in domestic animals, Velinova et al., in bovine and LieblerTenorio \& Pabst in calves.

In the young age group of sheep, palatine tonsils were well developed organized and pushed down from the surface epithelium due to development of connective tissue in between them. The parafollicular tissue was present between and beneath the follicles. Presence of medium-sized lymphocytes was predominant over the small-sized lymphocytes in the parafollicular region. The lymphoid tissue folded around the median septa, which sent thin strands of connective tissue (secondary septa) and merged with the parafollicular tissue.

The tonsillar follicles of the young sheep showed many medium and small sized lymphocytes, lymphoblasts and also reticulocytes. Typical small lymphocytes could be distinguished from other lymphocytic cells by their smaller size, relatively scantier cytoplasm, thicker peripheral rim of chromatin in the nucleus and the occasional presence of a deep indentation in the nuclear outline, which is corroborated, with the findings of Ferrarini et al. (1980), in mammals and King \& McLelland (1981) in birds.

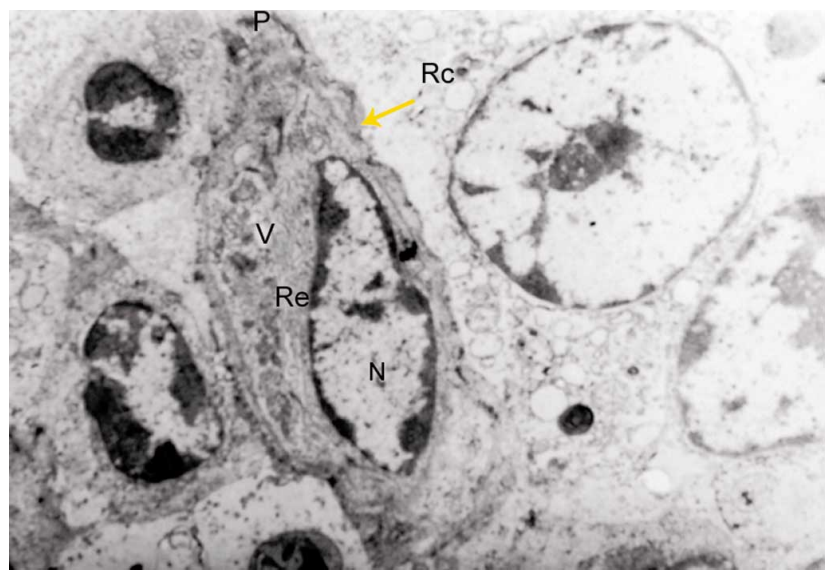

Fig. 5. Fig. 3. Transmission electronmicrograph of palatine tonsil of six month-old sheep showing reticular cells in the lymphoid follicle. Rc. Reticular cell; P. Process of reticular cell. V. Vacuole; N. Nucleus; Re. Rough endoplasmic reticulum. Uranyl acetate and Lead citrate x 7160 . 
The reticular cells usually appeared larger than lymphocytes and had a more abundant and organized cytoplasm. The nucleus was elongated with the chromatin spread irregularly in small masses and there was much narrower dense rim of chromatin beneath the nuclear membrane. The cytoplasm was darker and vacuoles were present. Cell processes were seen with filamentous substance with small groups of scattered ribosomes (Fig. 5), which is in accordance with the observations of Ritter \& Crispe (1992) in mammals.

RAJU, N. K. B.; RAMESH, G.; BASHA, S. H.; USHAKUMARY, S. \& KISHORE, P. V. S. Microarquitectura de la tonsila palatina en oveja (Ovis aries). Int. J. Morphol., 30(4):1474-180, 2012.

RESUMEN: Fueron recolectadas piezas de tejido desde la tonsila palatina de ovejas con diferentes edades postnatales, desde la Corporación Slaughter House, Perambur, Chennai. La tonsila palatina consistía en un epitelio de superficie, cápsula, lóbulos de las tonsilas, criptas, epitelio de las criptas tonsilares y folículos. El epitelio superficial sobre la tonsila palatina estaba compuesto, en todos los grupos estudiados, de epitelio escamoso estratificado no-queratinizado. La tonsila palatina se delimitó claramente de las estructuras circundantes por un tejido conectivo capsular y un septo dividiendo la tonsila en dos lóbulos. El epitelio superficial se invaginó dentro de de la tonsila para formar criptas primarias y secundarias en cada lóbulo. El epitelio de las criptas cubrió las regiones de folículos linfoides transfomándose en linfoepitelo. También se observaron macrófagos en el epitelio. En las áreas de linfoepitelo la membrana basal estaba interrumpida por la infiltración linfocitaria y fue mayor en el epitelio. Fueron observados numerosos folículos tonsilares secundarios con centros germinales separados por áreas interfoliculares. Los folículos tonsilares consistían en una zona del manto que estaba densamente poblada con pequeños linfocitos intensamente teñidos. Estas zonas del manto se orientaron siempre hacia las criptas. Los folículos tonsilares de las ovejas jóvenes mostraron muchos linfocitos de tamaño medianos y pequeños, linfoblastos y también reticulocitos. Las células reticulares usualmente aparecían más grandes que los linfocitos y tenían un citoplasma más abundante y organizado con vacuolas.

PALABRAS CLAVE: Ovejas; Tonsila palatina; Criptas; Folículos.

\section{REFERENCES}

Anderson, J. C. The response of the tonsil and associated lymph nodes of gnotobiotic piglets to the presence of bacterial antigen in the oral cavity. J. Anat., 117(Pt. 1):191-8, 1974.

Banks, W. J. Applied Veterinary Histology. $3^{\text {rd }}$ Ed. Missouri, Mosby Yearbook, 1993. pp.277-9.

Belz, G. T. \& Heath, T. J. Intercellular and lymphatic pathways of the canine palatine tonsils. J. Anat., 187(Pt. 1):93-105, 1995a.

Belz, G. T. \& Heath, T. J. The epithelium of canine tonsils. Anat. Embryol. (Berl.), 192(2):189-94, 1995b.

Bernstein, J. M.; Gorfein, J. \& Brandtzaeg, P. The immunobiology of the tonsils and adenoids. In: Pearay, O. L.; Mestecky, J.; Lamm, M. E.; Strober, W.; Bienenstock, J. \& McGhee, J. R. (Eds.). Mucosal Immunity. San Diego, Academic Press, 1999. pp.1339-62.

Bozzola, J. J. \& Russell, L. D. Electron Microscopy: Principles and Techniques for Biologists. 2nd Ed. London, Jones and Barlett Publishers, 1998. pp.19-144.

Brandtzaeg, P. Immune functions of human nasal mucosa and tonsils in health and disease. In: Bienenstock, J. (Ed.). Immunology of the lung and upper respiratory tract. New York, McGraw Hill Book Co., 1984. pp.28-95.

Castelyn, C.; Van den Broeck, W. \& Simoens, P. Histological characteristics and stereological volume assessment of the ovine tonsils. Vet. Immunol. Immunopathol., 120(3-4):124-35, 2007.

Cocquyt, G.; Baten, T.; Simoens, P. \& Van den Broeck, W. Anatomical localisation and histology of the ovine tonsils. Vet. Immunol. Immunopathol., 107(1-3):79-86, 2005.

Cooper, M. D.; Gabrielsen, A. E.; Peterson, R. D. A. \& Good, R. A Ontogenic development of the germinal centres and their function- relationship to the bursa of Fabricius. In: Cottier, H.; Odartchenko, N.; Schindler, R. \& Congdon, C. C. (Eds.). Germinal centres in immune responses. New York, SpringerVeralag, 1967. pp.28-33.

Cross, P. C. \& Mercer, K. L. A textbook on cell and tissue ultrastructure. New York, W. H. Freeman and Company, 1993.

Curran, R. C. \& Jones, E. L. Immunoglobulin containing cells in human tonsils as demonstrated by immunohistochemistry. Clin. Exp. Immunol., 28(1):103-15, 1977.

Dellmann, H. D. \& Eurell, J. A. Textbook of Veterinary Histology. $5^{\text {th }}$ Ed. Baltimore, Williams and Wilkins Co., 1998. pp.137-91.

Ferrarini, M.; Cadoni, A.; Franzi, A. T.; Ghigliotti, C.; Leprini, A.; Zicca, A. \& Grossi, C. E. Ultrastructure and cytochemistry of human peripheral blood lymphocytes. Similarities between the cells of the third population and TG lymphocytes. Eur. J. Immunol., 10(7):562-70, 1980. 
Higashikawa, T.; Ohtani, O. \& Masuda, Y. Ultrastructures of the epithelial basement membrane and the subepithelial capillaries in rabbit palatine tonsils. Arch. Histol. Cytol., 53(1):31-9, 1990.

Howie, A. J. Scanning and transmission electron microscopy on the epithelium of human palatine tonsils. J. Pathol., 130(2):91-8, 1980.

Karchev, T. \& Kabakcheiv, P. Electron microscopic observations on the tonsillar epithelium in children with recurrent tonsillitis. Int. J. Pediatr. Otorhinolaryngol., 4(2):149-56, 1982.

King, A. S. \& McLelland, J. Form and function in birds. London, Academic Press, 1981. pp.352-9.

Liebler-Tenorio, E. M. \& Pabst, R. MALT structure and function in farm animals. Vet. Res., 37(3):257-80, 2006.

Luna, L. G. Manual of Histological Staining Methods of the Armed forces Institute of Pathology. $3^{\text {rd }}$ Ed. New York, McGraw Hill Book Co., 1968. pp.82-194.

Morente, M.; Piris, M. A.; Orradre, J. L.; Rivas, C. \& Villuendas, R. Human tonsil intraepithelial B-cells: a marginal zone related subpopulation. J. Clin. Pathol., 45(8):668-72, 1992.

Nave, H.; Gebert, A. \& Pabst, R. Morphology and immunology of the human palatine tonsil. Anat. Embryol. (Berl.), 204(5):367-73, 2001.

Nickel, R. A.; Schummer, E. \& Seiferle, E. The viscera of the domestic animals. Berlin, Verlag Paul Parley, 1979. pp.526.

Noden, D. M. \& de Lahunta, A. The embryology of domestic animals. Baltimore, Williams and Wilkins, 1985. p.178.

Palmer, M. V.; Thacker, T. C. \& Waters, W. R. Histology, immunohistochemistry and ultrastructure of the bovine palatine tonsil with special emphasis on reticular epithelium. Vet. Immunol. Immunopathol., 127(3-4):277-85, 2009.

Perry, M. E. \& Mustafa, Y. Distribution of antigen presenting cells in tonsillar epithelium. J. Anat., 180(Pt. 2):365, 1992.

Perry, M. E. The specialized structure of crypt epithelium in the human palatine tonsil and its functional significance. J. Anat., 185(Pt. 1):111-27, 1994.

Perry, M. \& Whyte, A. Immunology of tonsils. Immunol. Today, 19(9):414-421, 1998.

Rappolee, D. A. \& Werb, Z. Macrophage derived growth factors. Curr. Top. Microbiol. Immunol., 181:87-140, 1992.

Ritter, M. A. \& Crispe, I. N. The Thymus. London, Oxford IRL Press, 1992. pp.1-85.

1486
Singh, U. B. \& Sulochana, S. Handbook of Histological and Histochemical Techniques. $2^{\text {nd }}$ Ed. Hyderabad, Premier publishing house, 1996. pp.84-102.

Thuring, C. M.; Crowe, M. A.; McAllister, H.; Earley, B.; Roche, J. F. \& Sweeney, T. Evaluation of peripheral lymphoreticular biopsy techniques and their clinical side effects in sheep. Vet. Rec., 150(4):97-102, 2002.

Velinova, M.; Thielen, C.; Mélot, F.; Donga, J.; Eicher, S.; Heinen, E. \& Antoine, N. New histochemical and ultrastructural observations on normal bovine tonsils. Vet. Rec., 149(20):6137, 2001.

Williams, D. M. \& Rowland, A. C. The palatine tonsils of the pigan afferent route to the lymphoid tissue. J. Anat., 113(1):1317, 1972.

Correspondence to:

N. K. B. Raju

Dept. of Veterinary Anatomy, NTR.

College of Veterinary Science

Gannavaram - 521 102, Krishna (Dt)

Andhra Pradesh

INDIA

Phone: +91-9666636767

Fax: $+91-8676-252335$

Email:nkbraju@gmail.com

Received: 27-03-2012

Accepted: 30-07-2012 